\title{
STATISTICAL STUDY OF THE PRIMARY-DENDRITE SPACINGS IN SINGLE-CRYSTAL SUPERALLOYS
}

\author{
STATISTIČNA ANALIZA PRIMARNIH MEDDENDRITNIH \\ PROSTOROV V MONOKRISTALNI SUPERZLITINI
}

\author{
Xiaoli Zhang', Tingzhen Xin ${ }^{1}$, Shuaishuai Yue ${ }^{1}$, Xiangbin Meng ${ }^{2}$, Guiqun Liu ${ }^{1 *}$ \\ ${ }^{1}$ School of Material Science and Engineering, North Minzu University, Yinchuan 750021, China \\ ${ }^{2}$ School of Mechanical and Automotive Engineering, Qilu University of Technology, Shandong Academy of Sciences, Jinan 250353, China
}

Prejem rokopisa - received: 2020-08-13; sprejem za objavo - accepted for publication: 2020-10-05

doi: $10.17222 / \mathrm{mit} .2020 .161$

\begin{abstract}
Three generations of single-crystal superalloys (AM3, DD5 and DD90) were produced with directional solidification and seeding. The square-calculation method and direct-measurement method were used to study the primary-dendrite spacings of the three single-crystal superalloys at different solidification distances $(50,150$ and 250$) \mathrm{mm}$. Statistical results showed that, firstly, as the solidification heights increased, the average primary-dendrite spacings of the three alloys were gradually enlarged; secondly, the average primary-dendrite spacings calculated with the square-calculation method and the direct-measurement method were similar, which indicated the high precision of the two methods; thirdly, the primary-dendrite spacings of the three alloys were distributed randomly in a relatively large range, following a normal distribution. The maximum values of the primary-dendrite spacings were 4.7-8.5 times larger than the minimum ones at different solidification distances and were different from the values from previous studies.

Keywords: directional solidification, seeding, single-crystal superalloy, primary-dendrite spacing
\end{abstract}

Avtorji so izdelali tri generacije monokristalnih superzlitin (AM3, DD5 in DD90) s postopkom direktnega strjevanja in sejanja. Uporabili so računsko metodo kvadratov in direktne meritve za študij razdalje med primarnimi dendritnimi vejami treh monokristalnih superzlitin na različnih razdaljah strjevanja na $(50,150$ in 250) $\mathrm{mm}$. Statistični rezultati študije so pokazali: 1) da solidifikacijska višina narašča in da povprečna primarna velikost meddendritnih prostorov postopno narašča za vse tri preiskovane zlitine; 2)drugič: da sta si povprečni velikosti primarnih dendritnih medprostorov, izračunanih z računsko metodo kvadratov in metodo direktnega merjenja, podobni kar kaže na visoko natančnost obeh metod ter 3) primarni dendritni medprostori vseh treh preiskovanih zlitin so porazdeljeni naključno in v relativno širokem območju sledijo normalni velikostni porazdelitvi. Maksimalne vrednosti velikosti primarnih meddendritnih prostorov so 4,7-krat do 8,5-krat večje od najmanjših pri različnih razdaljah strjevanja, kar se razlikuje od predhodnih raziskav.

Ključne besede: direktno strjevanje, sejanje, monokristalna superzlitina, primarni meddendritni prostori

\section{INTRODUCTION}

The directional-solidification technology is one kind of casting technique. According to this technique, molten materials solidify along the opposite direction of the heat flow when the unidirectional temperature gradient between the solid and melt is built using a special method, which is to ensure the growth direction of crystals in parallel and contrary to the direction of the heat flow. ${ }^{1}$ During solidification, a negative temperature gradient appears when the temperature at the solid-liquid interface goes up due to the latent heat of crystallization. Thus, the liquid phase is in the supercooled condition. Under this circumstance, the solid-liquid interface is unlikely to be flat-shaped. Instead, a lot of of dendrites (the so-called primary dendrites) start growing into the liquid with some secondary dendrites formed on the crystal axis. ${ }^{2}$ By studying the primary-dendrite spacing, we can evaluate the dendritic structure of materials, which is decisive for the material performance. ${ }^{1,3}$

*Corresponding author's e-mail:

gqliu10b@alum.imr.ac.cn (Guiqun Liu)
Due to the disappearing of crystal boundaries, Ni-based single-crystal superalloys exhibit excellent high-temperature properties and are preferred materials for aero-engine turbine blades. ${ }^{4-9}$ Due to the use of the seeding method or selecting method, the structure of a single-crystal superalloy includes cross-shaped dendrites, making a significant effect on the thermo-mechanical properties and heat treatment of the single-crystal superalloy. ${ }^{6}$

According to the earlier theoretical and experimental studies, there is a relationship between primary-dendrite spacing and solidification parameters $\left(c_{0}, G_{\mathrm{L}}, v\right)$, or superalloy properties, and a theoretical model of the dendritic-structure characteristic parameter was also established. ${ }^{10-16}$ However, a lot of recent research. ${ }^{13,17-20}$ proved that there is a wide range of tolerance for stable primary-dendrite spacing under a given solidification condition. The tolerance of dendrite spacing is related to the solidification history. J. D. Hunt et al. ${ }^{13,21}$ indicated that the biggest spacing between dendrites or crystal cells is twice the size of the lowest one. Furthermore, G. L. Ding et al. ${ }^{17}$ revealed that the biggest spacing between dendrites or crystal cells is more than twice the 
Table 1: Chemical compositions of the three alloys $(w / \%)$

\begin{tabular}{|c|c|c|c|c|c|c|c|c|c|c|c|}
\hline Alloys & $\mathrm{Cr}$ & $\mathrm{Co}$ & $\mathrm{Mo}$ & $\mathrm{Re}$ & $\mathrm{W}$ & $\mathrm{Al}$ & $\mathrm{Ti}$ & $\mathrm{Ta}$ & $\mathrm{Hf}$ & $\mathrm{C}$ & $\mathrm{Ni}$ \\
\hline AM3 & 8 & 5.5 & 2.2 & - & 5 & 6 & 2 & 3.5 & - & - & $\mathrm{Bal}$. \\
\hline DD5 & 6.9 & 7.6 & 1.6 & 3.1 & 5.3 & 6.2 & - & 6.6 & 0.14 & 0.038 & $\mathrm{Bal}$. \\
\hline DD90 & 5 & 12 & 1 & 5 & 6 & 6 & - & 8 & - & - & Bal. \\
\hline
\end{tabular}

size of the lowest one, but they did not specify how many times it occurs. In fact, a lot of errors cannot be avoided during a dendrite-spacing measurement because of the diversity of the crystallographic orientations and crystal boundaries in polycrystalline materials. For this reason, it is necessary to examine the dimensions of a primary-dendrite spacing without the diversity in the crystallographic orientations and crystal boundaries.

A primary-dendrite spacing refers to the spacing between primary-dendrite axes of two neighboring dendrites. As for now, the most accurate measurement of a primary-dendrite spacing is the direct-measurement method. Although the direct-measurement method is more accurate, it requires massive work. However, in metallic materials, cross-shaped dendrites grow in a square pattern, indicating axes of primary dendrites arranged in the form of a square lattice, which means that the primary-dendritic spacing can be determined with the number of the lattice squares. This method is called the square-calculation method, which is simple and requires less work. The materials used in this study were three kinds of a Ni-based superalloy (the first-generation AM3, the second-generation DD5 and the third-generation DD90). The three superalloys were [001] singlecrystal superalloys made with the seeding method.

\section{EXPERIMENTAL PART}

The chemical compositions of the three single-crystal superalloys (AM3, DD5 and DD90) used in the present work are listed in Table $\mathbf{1}$. In order to assure the same compositions of the samples and seeds, the chemical compositions of the cast superalloys and seeds are the same as in Table $\mathbf{1}$.

The three Ni-based single-crystal superalloys were produced with directional solidification and seeding in order to eliminate the effects of the grain boundaries and crystallographic orientation on the primary-dendrite spacings. To ensure the directions of the dendritic growth and thermal gradient are the same, the [001] direction of every seed was aligned to the growth direction and the $[010] /[100]$ direction was parallel or vertical to the platform edges. The length, width and height of every seed were $8 \times 8 \times 18 \mathrm{~mm}$. The length, width and height of every specimen were $10 \times 10 \times 300 \mathrm{~mm}$.

Directional experiments were performed in a Bridgman high-rate solidification (HRS) furnace with a twin-zone resistance heater. In order to obtain a partial melt of the top of every seed, the mold was preheated to $1600{ }^{\circ} \mathrm{C}$. At the same time, the superalloy was superheated to $1600{ }^{\circ} \mathrm{C}$ and kept at the temperature for $5 \mathrm{~min}$ to homogenize the melt. The melt was then poured into an empty mold. Its dwell time was $10 \mathrm{~min}$ to ensure the system reached thermal equilibrium. Then, the mold was at a constant speed of $6 \mathrm{~mm} / \mathrm{min}$. The samples were cleaned when the mold shells were cooled to room temperature.

Cross-section samples at different solidification distances $(50,150$ and 250) $\mathrm{mm}$ were cut with wire cutting and used to investigate the dendritic structure with a LEICA optical microscope. All the samples were micro-etched in a mixture of $\mathrm{HCl}(80 \mathrm{~mL})+\mathrm{H}_{2} \mathrm{SO}_{4}(5 \mathrm{~mL})$ $+\mathrm{CuSO}_{4}(20 \mathrm{~g})+\mathrm{H}_{2} \mathrm{O}(100 \mathrm{~mL})$. Finally, primary-dendrite spacings were calculated using metallographic images and image-analysis software Image-Pro Plus 6.0. In order to reduce experimental errors, the same metallographic images were used for direct measurement and square calculation.

Primary-dendrite spacing is the distance between the dendritic trunks of two adjacent dendrites, so the most accurate statistical method of primary-dendrite spacing is direct measurement. This method is carried out as follows: the distance between the dendritic trucks of two adjacent dendrites is measured directly. After many measurements, the average values are taken. In this study, the metallographic images were opened in Image-Pro Plus 6.0. The primary-dendritic spacings of the adjacent dendrites were measured directly and the average primary-dendritic spacings were calculated after multiple measurements.

In metal materials, cross-shaped dendrites are generally arranged in a square pattern, that is to say, four dendrites around a dendrite form a square. Therefore, the square-calculation method is carried out as follows: firstly, a large number of transverse metallographic images at different locations are taken with a metallographic microscope. Secondly, the number of dendrites in each image is counted as the N. The dendrite trunk of each dendrite is taken as the counting point in statistics. A dendrite trunk is neglected when it is outside the image boundary. A dendrite trunk is 0.5 of a counting point at the image boundary, and it is one counting point when it is inside the image. Then, the $\mathrm{S}$ area of the image is calculated in accordance with the magnification of the image. Finally, the average primary-dendrite spacing is defined as: $\lambda_{1}=(S / N)^{0.5}$.

\section{RESULTS AND DISCUSSION}

\subsection{Dendrite morphology}

Figure 1 shows dendritic morphologies of the transverse section of the AM3 single-crystal superalloy at dif- 

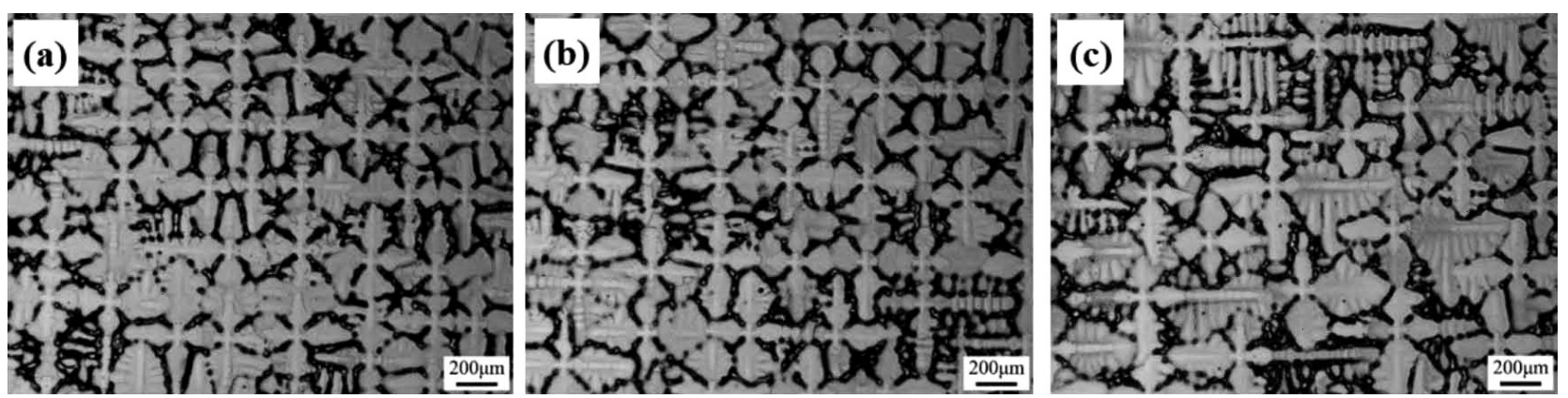

Figure 1: Optical micrographs showing the transverse microstructures of AM3 alloy at different solidification heights and a 50× magnification: a) $50 \mathrm{~mm}$; b) $150 \mathrm{~mm}$; ) $250 \mathrm{~mm}$

ferent solidification distances after directional solidification. The dendritic morphologies are cross-shaped and the direction of the secondary-dendrite arm is the same. However, the adjacent dendrites are not arranged in a square. By comparing the transverse microstructures at different solidification heights, it was found that with an increase in the solidification height, the tertiary-dendrite arms become more and more developed. As shown in Figure 1c, a large number of tertiary-dendrite arms appear at a solidification height of $250 \mathrm{~mm}$. In addition, the dendrite morphologies of the three alloys (AM3, DD5 and DD90) were found to be identical when the transverse microstructures of the three alloys were compared.

\subsection{Statistics of primary-dendrite spacing}

According to the square-calculation method, the more dendrites are counted, the fewer errors are generated during the statistical treatment of the average primary-dendrite spacing. In order to reduce the errors, we selected metallographic pictures at a $15 \times$ magnification. It was found that the number of dendrites in the metallographic pictures of the three superalloys with different solidification heights $(50,150$ and 250) $\mathrm{mm}$ was about 400-600. Then, the average primary-dendrite spacing was calculated with the following formula: $\lambda_{1}=$ $(S / N)^{0.5}$. The average primary-dendrite spacings are shown with the black histograms in Figure 2. When the solidification heights are the same, the average primary-dendrite spacing of the first-generation AM3 alloy is slightly larger than those of the second-generation DD5 and third-generation DD90. Also, the average primary-dendrite spacings of the second-generation DD5 and third-generation DD90 are approximately the same.

In order to reduce the errors of direct measurement, the primary-dendrite spacing of every alloy was measured 500-1000 times at the same solidification height. The average primary-dendrite spacings are shown with the histograms in Figure 2. For the square-calculation method and direct-measurement method, the change rule for the average primary-dendrite spacing was identical. When the solidification height was the same, the average primary-dendrite spacing of the first-generation AM3 alloy was slightly larger than those of the second-generation DD5 and third-generation DD90. In addition, the average primary-dendrite spacings of the second-generation DD5 and third-generation DD90 were similar.

When comparing the average primary-dendrite spacing calculated with the square-calculation method and direct-measurement method, it was found that the difference between the two methods was small, showing that the accuracy of the square-calculation method is high. Although the accuracy of direct measurement is high, it is time-consuming and laborious. In order to improve the work efficiency, the square-calculation method can replace the direct-measurement method for calculating the primary-dendrite spacing.

The average primary-dendrite spacings of the three single-crystal superalloys are shown in Figure 3. With the increase in the solidification height, the average pri- (a)

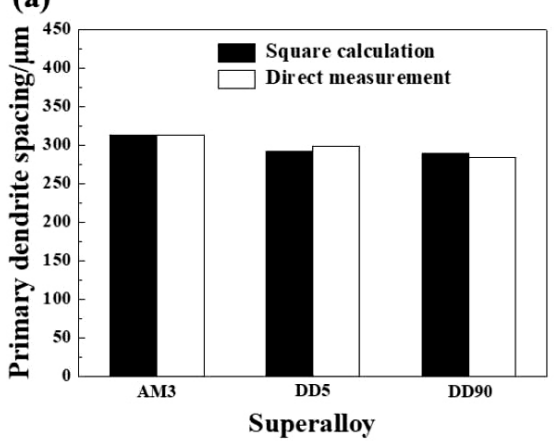

(b)

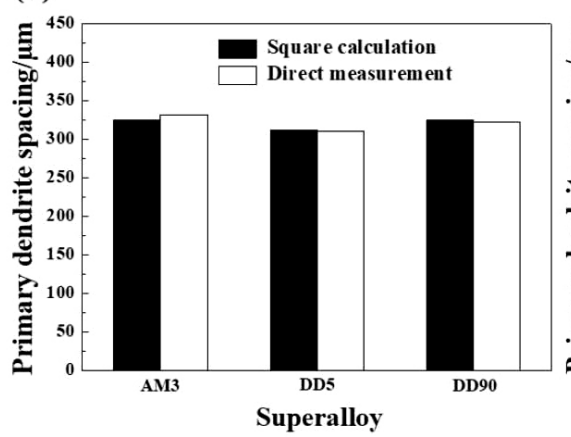

(c)

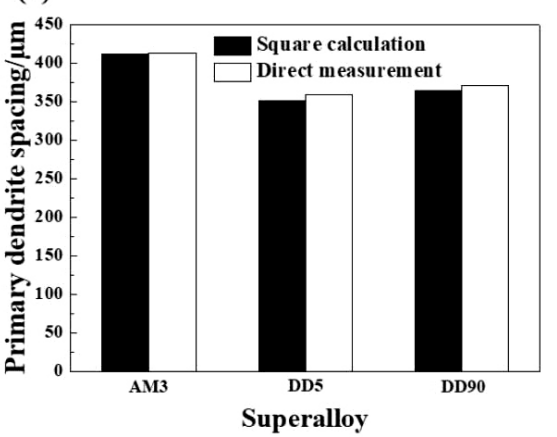

Figure 2: Average primary-dendrite spacings of the three alloys: a) $50 \mathrm{~mm}$ solidification height, b) $150 \mathrm{~mm}$ solidification height, c) $250 \mathrm{~mm}$ solidification height 


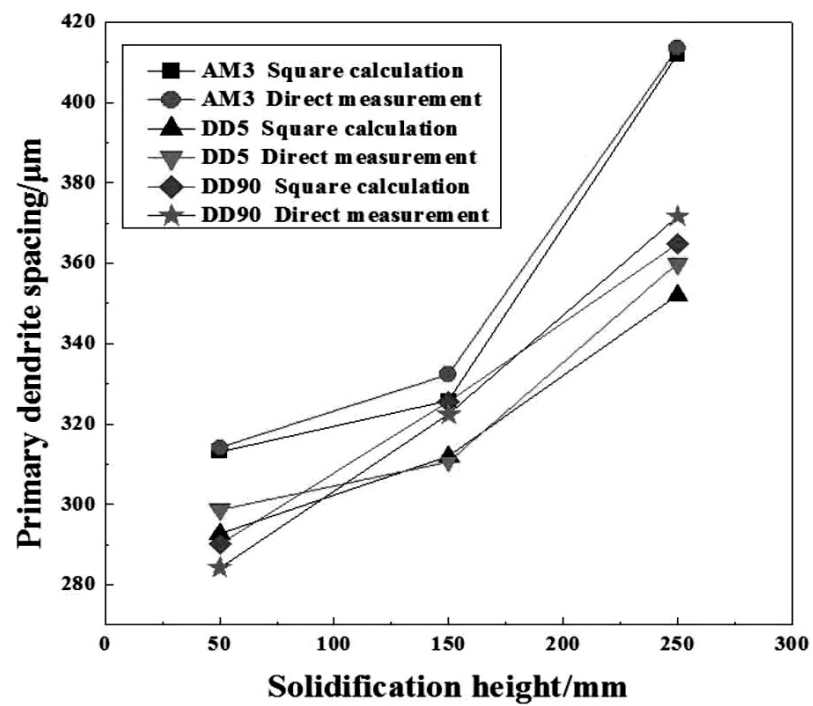

Figure 3: Average primary-dendrite spacings of the three superalloys at different solidification heights

mary-dendrite spacings of the three alloys increased significantly. Especially in the later stage of solidification, the average primary-dendrite spacing increased faster than in the earlier stage. In addition, the average primary-dendrite spacing of the first-generation single-crystal superalloy AM3 was slightly larger than those of the second-generation DD5 and third-generation DD90.
However, there was no significant difference between the second-generation DD5 and third-generation DD90.

The primary-dendrite spacings of the AM3 superalloy were measured 955 times, 934 times and 578 times, respectively, at solidification heights of $(50,150$ and 250) $\mathrm{mm}$. Specific values of the primary-dendrite spacings are shown in Figure 4. The primary-dendrite spacing was not a certain value, but a relatively large range of random change. The primary-dendrite spacings were mainly distributed in a range of 100-600 $\mu \mathrm{m}$. In addition, the primary-dendrite spacings were measured 1129 times, 956 times and 1023 times, respectively, at solidification heights of 50,150 and $250 \mathrm{~mm}$ of the DD5 superalloy. They were 1006 times, 912 times and 695 times larger than those of the DD90 superalloy. The variation rule of the primary-dendrite spacings of superalloys DD5 and DD90 was the same as that of superalloy AM3.

The lower and upper limits of the primary-dendrite spacings calculated with direct measurement are shown in Table 2. The primary-dendrite spacings of the three superalloys were distributed in a large range. There were upper and lower limits, which was consistent with earlier research conclusions. ${ }^{13,17,21}$ At different solidification heights of the three superalloys, the difference between the upper and lower limits of the primary-dendrite spacings was large. With the increase in the solidification height, the ratio of the upper limit to the lower limit was (6.9, 6.8 and 4.7) for superalloy AM3, respectively, (6.7, 8.5 and 5.0) for superalloy DD5 and (6.9, 8.5 and 6.8) for superalloy DD90. Therefore, the upper limit of the (a)

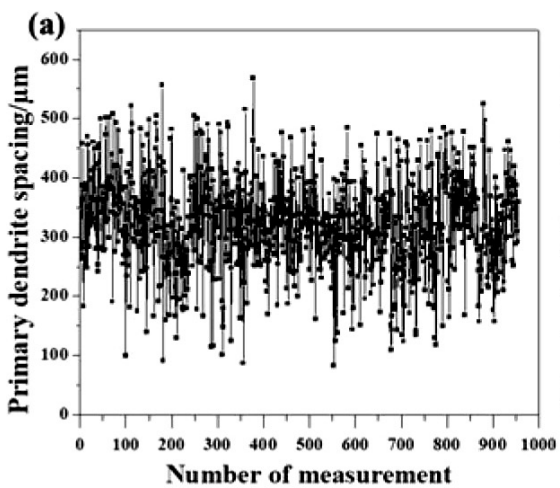

(b)

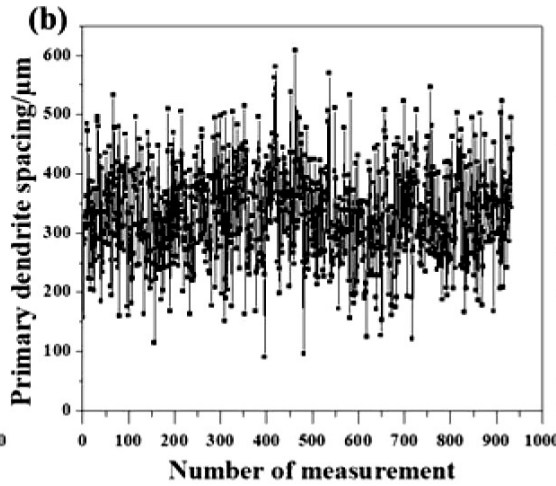

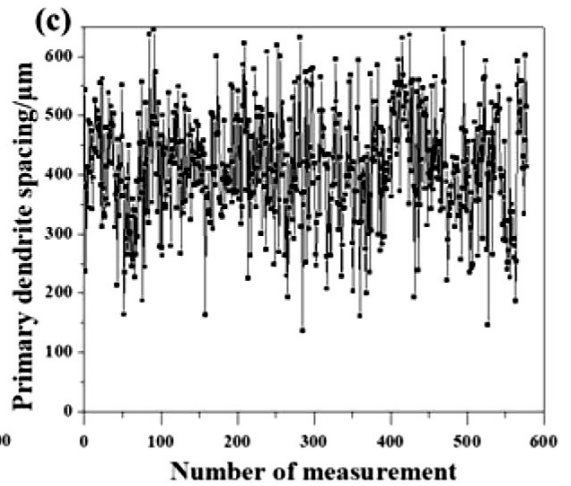

Figure 4: Primary-dendrite spacings at different solidification heights of the AM3 superalloy calculated with direct measurement: a) 50 mm; b) $150 \mathrm{~mm}$; c) $250 \mathrm{~mm}$

Table 2: Primary-dendrite spacings of the three superalloys calculated with direct measurement

\begin{tabular}{|c|c|c|c|c|c|c|c|c|c|}
\hline \multirow{2}{*}{ Superalloys } & \multicolumn{3}{|c|}{$50 \mathrm{~mm}$ height } & \multicolumn{3}{|c|}{$150 \mathrm{~mm}$ height } & \multicolumn{3}{|c|}{$250 \mathrm{~mm}$ height } \\
\hline & Lower limit & Upper limit & Ratio & Lower limit & Upper limit & Ratio & Lower limit & Upper limit & Ratio \\
\hline AM3 & 82 & 569 & 6.9 & 90 & 609 & 6.8 & 136 & 645 & 4.7 \\
\hline DD5 & 87 & 584 & 6.7 & 70 & 593 & 8.5 & 119 & 602 & 5.0 \\
\hline DD90 & 98 & 676 & 6.9 & 80 & 679 & 8.5 & 102 & 694 & 6.8 \\
\hline
\end{tabular}

Lower limit: the minimum value of the primary-dendrite spacings Upper limit: the maximum value of the primary-dendrite spacings Ratio: The ratio of the upper limit to the lower limit 
three superalloys was about 4.7-8.5 times higher than the lower limit. This was not consistent with the conclusions of references, ${ }^{17,21}$ as the difference is an almost doubled value. However, our conclusion is similar to that from reference ${ }^{13}$ where the difference is far more than a doubled value. Because the difference between the upper and lower limits of the primary-dendrite spacing is large, the actual primary-dendrite spacing generally refers to the average value, as shown in Figures 2 and 3.

\section{CONCLUSIONS}

(1) With the increase in the solidification height during directional solidification, the average primary-dendrite spacing of the three single-crystal superalloys increases gradually. Additionally, the increasing rate of the average primary-dendrite spacing in the late solidification stage is significantly higher than that in the early solidification stage.

(2) For the three single-crystal superalloys (AM3, DD5 and DD90), the difference in the average primary-dendrite spacing determined with the square-calculation method and direct-measurement method is not obvious, which indicates that the accuracy of both methods is high.

(3) The primary-dendrite spacings of the three single-crystal superalloys are distributed randomly in a relatively large range. The upper limit is 4.7-8.5 times higher than the lower limit. They are different from the values from the previous studies.

\section{Acknowledgements}

This work was supported by the Key Research and Development Program of Ningxia (2018BEE03017, 2019BDE03016) and the Natural Science Foundation of Ningxia (2018AAC03249).

\section{REFERENCES}

${ }^{1}$ W. Kurz, D. J. Fisher, Fundamentals of solidification, $3^{\text {rd }}$ edition, Trans Tech Publications, Aedermannsdorf, 1992

${ }^{2} \mathrm{G}$. Hu, X. Cai, Y. Rong, Fundamentals of Materials Science, $3^{\text {rd }}$ edition, Shanghai Jiaotong University Press, Shanghai, China 2014, 243
${ }^{3}$ M. C. Flemings, Solidification processing, McGraw-Hill, Inc., New York 1974

${ }^{4}$ R. C. Reed, The Superalloys: Fundamentals and Applications, Cambridge University Press, UK 2006, 141

${ }^{5}$ R. E. Schafrik, S. Walston, Challenges for high temperature materials in the new millennium, Superalloys 2008, TMS, Warrendale, PA, USA 2008, 3-9

${ }^{6}$ M. McLean, Directionally solidified materials for high temperature service, The Metals Society, London 1983, 161

${ }^{7}$ R. E. Shalin, I. L. Svetlov, E. B. Kachanov, V. N. Toloraiia, O. S. Gavrilin, Single Crystals of Nickel Superalloys, Mocshinostroeniye, Moscow 1997, 336

${ }^{8}$ K. P. L. Fullagar, R. W. Broom?eld, M. Hulands, K. Harris, G. L. Erickson, S. L. Sikkenga, Aero engine test experience with CMSX-4 alloy single-crystal turbine blades, J. Eng. Gas Turbines Power, 118 (1996), 380-388

${ }^{9}$ M. J. Goulette, P. D. Spilling, R. P. Arthey, Cost effective single crystals, Superalloys 1984, TMS Warrendale, PA, USA 1984, 167-176

${ }^{10}$ J. D. Hunt, Solidification and casting of metals, The Metal Society, London 1979, 3-12

${ }^{11}$ W. Kurz, D. J. Fisher, Dendrite growth at the limit of stability: tip radius and spacing, Acta Metal., 29 (1981) 1, 11-20

${ }^{12}$ R. Trivedi, Interdendritic spacing: Part II. A comparison of theory and experiment, Metall. Trans. A, 15 (1984), 977-982

${ }^{13}$ J. D. Hunt, S. Z. Lu, Numerical modeling of cellular/dendritic array growth: Spacing and structure predictions, Metall. Mater. Trans. A, 27 (1996), 611-623

${ }^{14}$ A. Warrenjames, J. S. Langer, Prediction of dendritic spacing in a directional-solidification experiment, Physics Review E, 47 (1993) 4, 2702-2712

${ }^{15}$ O. L. Rocha, C. A. Siqueira, A. Garcia, Heat Flow Parameters Affecting Dendrite Spacings during Unsteady-State Solidification of $\mathrm{Sn}-\mathrm{Pb}$ and Al-Cu Alloys, Metall. Mater. Trans. A, 34 (2003), 995-1006

${ }^{16}$ M. Gunduz, E. Cadirli, Directional Solidification of Aluminium-Copper Alloys, Mater. Sci. Eng. A, 327 (2002), 167-185

${ }^{17}$ Huang Weidong, Geng Xingguo, Zhou Yaohe. Primary spacing selection of constrained dendritic growth, Journal of Crystal Growth, 134 (1993), 105-115

${ }^{18}$ G. L. Ding, W. D. Huang, X. Huang, X. Lin, Y. H. Zhou, On primary dendritic spacing during unindirectional solidification, Acta Metallurgica et Materialia, 44 (1996) 9, 3705-3709

${ }^{19}$ S. H. Han, R. Trivedi, Primary spacing selection in directionally solidification alloys, Acta Metallurgica et Materialia, 42 (1994) 1, 25-41

${ }^{20}$ L. X. Li, X. Lin, M. Wang, W. D. Huang, Selection of Primary Dendritic Spacing during Directional Solidification of $\mathrm{Al}-3.6 \% \mathrm{Cu}$, Foundry Technology, 29 (2008), 891-895

${ }^{21}$ S.-Z. Lu, J. D. Hunt, P. Gilgien, W. Kurz, Cellular and dendritic array growth in rapidly solidified $\mathrm{Al}-\mathrm{Fe}$ and $\mathrm{Al}-\mathrm{Si}$ alloys, Acta Metallurgica et Materialia, 42 (1994), 1653-1660 